\title{
PENINGKATAN PEMAHAMAN KONSEP SISWA KELAS VII.1 SMP N 2 SINGARAJA MELALUI PENERAPAN MODEL PEMBELAJARAN KOOPERATIF TIPE TWO STAY TWO STRAY (TSTS)
}

\author{
L.P.A M. Setiawati, I.M. Sugiarta, I. G. P. Suharta \\ Jurusan Pendidikan Matematika Universitas Pendidikan Ganesha \\ Singaraja, Indonesia \\ e-mail: aryamelyana8@gmail.com, madesugiarta54@gmail.com, igpsuharta@yahoo.com
}

\begin{abstract}
ABSTRAK
Penelitian ini bertujuan untuk mendeskripsikan peningkatan pemahaman konsep matematika siswa dan tanggapan siswa melalui penerapan model pembelajaran kooperatif tipe TSTS. Jenis penelitian ini adalah penelitian tindakan kelas yang dilaksanakan dalam tiga siklus. Subjek penelitian ini adalah siswa kelas VII.1 SMPN 2 Singaraja sebanyak 32 siswa pada semester ganjil tahun ajaran 2018/2019. Data pemahaman konsep matematika siswa diukur menggunakan tes pemahaman konsep berbentuk uraian. Data tanggapan siswa diukur menggunakan angket. Data yang diperoleh dianalisis secara deskriptif. Hasil penelitian menunjukkan bahwa rata-rata nilai pemahaman konsep dari siklus ke siklus berturut-turut, yaitu 63,$44 ; 74,69$; dan 81,88 dengan rata-rata nilai mengalami peningkatan dari siklus ke siklus secara berturut-turut, yaitu 7,19 dan 11,25. Peningkatan pemahaman konsep matematika siswa terjadi karena guru memberikan pengawasan lebih intensif terhadap siswa dalam pengerjaan LKS dengan menggunakan model pembelajaran kooperatif tipe TSTS. Kegiatan pembelajaran yang dilakukan memberikan kesempatan kepada siswa untuk menemukan sendiri konsep yang akan dipelajari. Selain itu, siswa merespon positif model kooperatif tipe TSTS.
\end{abstract}

Kata Kunci : pemahaman konsep matematika, model pembelajaran kooperatif tipe TSTS(two stay two

stray), tanggapan siswa

\begin{abstract}
This study is aiming to describe an increase in understanding of students' mathematical concepts and student responses through the application of the TSTS type cooperative learning model. This type of research is classroom action research conducted in three cycles. The subjects of this study were students of class VII.1 SMPN 2 Singaraja as many as 32 students in the odd semester of the 2018/2019 academic year. Data on understanding students' mathematical concepts was measured using concept understanding tests in the form of descriptions. Student response data was measured using a questionnaire. The data obtained were analyzed descriptively. The results of the study show that the average value of understanding concepts from cycle to successive cycles is $63.44 ; 74.69$; and 81.88 with the average value increasing from cycle to cycle in a row, namely 7.19 and 11.25. Increased understanding of students' mathematical concepts because teacher provide more intensive supervision of students in the work of LKS used the model cooperative type TSTS. Learning activities carried out provide an opportunity for students to find their own concepts to be learned. In addition, the students respond are positively to the cooperative learning model of the TSTS type.
\end{abstract}

Keywords: mathematical concept understanding, cooperative learning model of the TSTS type, students responses

\section{PENDAHULUAN}

Mutu dan kualitas pendidikan menjadi hal mutlak yang diperlukan untuk mencapai sumber daya manusia yang mampu bersaing. Dalam mewujudkan citacita tersebut ternyata masih banyak persoalan yang memengaruhi, salah satunya yaitu rendahnya pemahaman konsep siswa dalam pembelajaran, khususnya dalam mata pelajaran matematika. Matematika merupakan ilmu yang memiliki berbagai manfaat, baik bagi pengembangan kemampuan berpikir, pembentukan sikap maupun memecahkan masalah. Oleh karena itu, matematika mempunyai peran yang sangat penting dalam meningkatkan kualitas pendidikan. 
Sebagai fasilitator dalam kegiatan pembelajaran, guru diharapkan mengurangi perannya dalam pelaksanaan pembelajaran. Dwipayana (2012) menyatakan bahwa, demi mencapai tujuan pembelajaran matematika, guru telah mengupayakan berbagai cara untuk memperbaiki permasalahan pembelajaran matematika, seperti penerapan student centered, tetapi dalam penerapannya masih belum maksimal. Hal ini berdampak pada kemampuan siswa dalam memahami konsep dalam pembelajaran matematika. Keluhan seperti ini yang menyebabkan banyak sekolah mengalami permasalahan dalam pembelajaran matematika di kelas, salah satunya di SMP Negeri 2 Singaraja.

Berdasarkan wawancara dengan guru mata pelajaran matematika kelas VII.1 SMP N 2 Singaraja diperoleh hasil bahwa pembelajaran dikelas masih didominasi oleh guru, baik dalam menyampaikan materi maupun proses memperoleh informasi penting terkait kegiatan pembelajaran yang sedang berlangsung, akibatnya pembelajaran menjadi pasif yang mana hal tersebut menyebabkan kurang bermaknanya proses pembelajaran yang dialami siswa. Siswa cenderung menunggu jawaban dari guru ketika diberikan suatu permasalahan, serta siswa hanya berusaha menghapal rumus yang ada sehingga mengalami kesulitan apabila dihadapkan pada suatu permasalahan.

Pada saat wawancara peneliti mendapatkan hasil observasi di kelas VII.1 SMP N 2 Singaraja terdapat beberapa permasalahan yang menjadi penyebab rendahnya pemahaman konsep siswa, yaitu sebagai berikut: (1)Guru mengawali pembelajaran di kelas dengan penyajian konsep yang akan dipelajari secara singkat. Setelah itu, siswa diminta untuk mengerjakan soal latihan yang ada di buku. Pembelajaran hanya difokuskan pada kemampuan siswa dalam menghitung dan mendapatkan jawaban yang benar dari hasil perhitungan yang dilakukan. Siswa pun juga hanya fokus pada penyelesaian soal yang menyebabkan siswa tidak mampu memahami konsep dengan maksimal, (2)Siswa kesulitan dalam mengaplikasikan konsep yang dimiliki untuk memecahkan suatu permasalahan, ini terlihat ketika guru memberikan permasalahan siswa terlihat bingung dalam memahami kalimat atau pernyataan pada soal sehingga apa yang diketahui dan apa yang ditanyakan belum bisa artikan dengan benar, (3)Siswa belum mampu mengaitkan pengetahuan yang telah dipelajari sebelumnya dengan pengetahuan baru yang akan siswa pelajari, ini nampak ketika guru memberi materi baru yang ada kaitannya dengan materi sebelumnya siswa terlihat kebingungan dan lupa, (4)Siswa belum mampu dalam membuat atau menarik kesimpulan berupa argumen dari siswa itu sendiri dalam memperkuat jawabannya. Keadaan ini mengakibatkan kurangnya pemahaman konsep yang dimiliki siswa, lebih tepatnya pada indikator menyatakan ulang kembali konsep dengan kata-kata sendiri serta menjelaskan contoh dan bukan contoh, (5)Guru berupaya untuk melakukan pembelajaran inovatif akan tetapi dalam penerapannya guru masih mendominasi kegiatan pembelajaran. Dilihat dari guru menjelaskan langsung konsep-konsep dan memberikan permasalahan langsung dengan penyelesaiannya, sehingga siswa kurang diberi kesempatan dalam menemukan konsep sendiri, dan mengakibatkan konsep tidak lama diingat dan pembelajaran menjadi kurang bermakna, (6)Pembelajaran di kelas kurang memanfaatkan kelompok, sehingga kurang adanya diskusi atau kegiatan tanya jawab antara guru dengan siswa maupun siswa dengan siswa, atau dapat dikatakan kelas pasif.

Berdasarkan permasalahan yang telah di paparkan di atas, nampak bahwa perlu adanya upaya perbaikan proses pembelajaran di kelas, hal tersebut dikarenakan pemahaman konsep siswa kelas VII.1 SMP N 2 Singaraja yang masih rendah. Siswa sebaiknya tidak hanya menerima apa yang diberikan guru, tetapi mengonstruksi sendiri pengetahuannya agar siswa lebih mudah menyelesaikan permasalahan-permasalahan yang diberikan. Salah satu cara untuk memperbaiki proses pembelajaran di kelas agar pembelajaran tersebut agar siswa mampu memahami konsep selama proses pembelajaran adalah dengan menerapkan model pembelajaran Kooperatif tipe Two Stay Two Stray (TSTS). Dengan 
menerapkan model pembelajaran kooperatif tipe TSTS, siswa diarahkan untuk menemukan sendiri makna dari suatu permasalahan ataupun materi yang sedang dipelajari. Siswa tidak hanya duduk dan mendengarkan penjelasan guru, melihat guru mengerjakan permasalahan di papan, dan mencatat ketika diminta mencatat oleh guru. Tetapi siswa diarahkan untuk aktif mengonstruksi pengetahuaanya agar menemukan makna dari permasalahanpermasalahan yang diberikan sehingga memahami apa sebenarnya konsep-konsep kunci pada permasalahan yang diberikan.

Struktur TSTS memberi kesempatan kepada kelompok untuk membagi hasil dan informasi dengan kelompok lain. Roger dan David Johnson mengatakan bahwa tidak semua belajar kelompok bisa dianggap pembelajaran kooperatif. Untuk mencapai hasil yang maksimal, lima unsur dalam model pembelajaran kooperatif harus diterapkan. Lima unsur tersebut adalah : (1) saling ketergantungan positif, (2) tanggung jawab perseorangan, (3) tatap muka, (4) komunikasi antar kelompok, (5) evaluasi proses kelompok. Pada saat anggota kelompok bertamu ke kelompok lain maka akan terjadi proses pertukaran informasi yang bersifat saling melengkapi, dan pada saat kegiatan dilakukan maka akan terjadi proses tatap muka antar siswa dimana terjadi komunikasi baik dalam kelompok maupun antar kelompok sehingga siswa tetap mempunyai tanggung jawab peseorangan. Adapun langkah-langkah METODE

Penelitian yang akan dilaksanakan adalah penelitian tindakan kelas (classroom action research) yang secara umum bertujuan meningkatkan dan memperbaiki kualitas, proses, dan hasil pembelajaran matematika di kelas. Penelitian ini dilaksanakan dalam 3 (tiga) siklus. Dalam penelitian ini, PTK yang digunakan adalah model Kurt Lewin. Menurut Kurt Lewin model pembelajaran kooperatif tipe TSTS menurut Huda adalah (1) siswa bekerja sama dalam kelompok berempat seperti biasa, (2) setelah selesai, dua siswa dari masing-masing kelompokakan meninggalkan kelompoknya dan masingmasing bertamu ke kelompok yang lain, (3) dua siswa tinggal dalam kelompok yang bertugas membagikan hasil kerja dan informasi ke tamu, (4) tamu mohon diri dan kembali ke kelompok mereka sendiri dan melaporkan temuan mereka dari kelompok lain, (5) kelompok mencocokan dan membahas hasil kerja mereka.

Pembelajaran kooperatif tipe Two Stay Two Stray(TSTS) adalah model pembelajaran kooperatif yang dapat mendorong anggota kelompok untuk memperoleh konsep secara mendalam melalui pemberian peran pada siswa. Siswa di ajak untuk bergotong royong dalam menemukan suatu konsep. Penggunaan model pembelajaran kooperatif TSTS akan mengarahkan siswa untuk aktif, baik dalam berdiskusi, tanya jawab, mencari jawaban, menjelaskan dan juga menyimak materi yang dijelaskan oleh teman.

Adapun tujuan dari penelitian ini adalah untuk mengetahui: (1) Untuk mendeskripsikan peningkatan kemampuan pemahaman konsep matematika siswa kelas VII.1 SMP N 2 Singaraja melalui penerapan model pembelajaran TSTS, (2) Untuk mengetahui tanggapan siswa Kelas VII.1 SMP N 2 Singaraja terhadap penerapan model pembelajaran TSTS.

(dalam Sanjaya, 2009) setiap siklus terdiri atas 4 (empat) tahap yaitu perencanaan tindakan, pelaksanaan tindakan, observasi dan evaluasi serta refleksi. Data pemahaman konsep matematika dikumpulkan menggunakan tes uraian yang diberikan pada setiap akhir siklus. Adapun rubrik peskoran pemahaman konsep matematika siswa adalah sebagai berikut.

Tabel 1. Rubrik Penskoran Pemahaman Konsep Matematika 


\begin{tabular}{|c|c|c|}
\hline Indikator & Kriteria Jawaban & Skor \\
\hline \multirow{3}{*}{$\begin{array}{l}\text { 1. Menyatakan ulang } \\
\text { konsep dengan kata- } \\
\text { kata sendiri }\end{array}$} & $\begin{array}{l}\text { Menyatakan ulang suatu konsep dengan kata- } \\
\text { kata sendiri dengan benar }\end{array}$ & 2 \\
\hline & $\begin{array}{l}\text { Menyatakan ulang suatu konsep dengan kata- } \\
\text { kata sendiri tetapi tidak sepenuhnya benar. }\end{array}$ & 1 \\
\hline & $\begin{array}{l}\text { Salah dalam menyatakan ulang suatu konsep } \\
\text { dengan kata- kata sendiri }\end{array}$ & 0 \\
\hline \multirow{3}{*}{$\begin{array}{l}\text { Mengidentifikasi } \\
\text { yang termasuk } \\
\text { contoh atau bukan } \\
\text { contoh dari konsep } \\
\text { yang diperoleh }\end{array}$} & $\begin{array}{l}\text { Mengidentifikasi yang termasuk contoh atau } \\
\text { bukan contoh dari konsep yang diperoleh dengan } \\
\text { benar }\end{array}$ & 2 \\
\hline & $\begin{array}{l}\text { Mengidentifikasi yang termasuk contoh atau } \\
\text { bukan contoh dari konsep yang diperoleh tetapi } \\
\text { tidak sepenuhnya benar }\end{array}$ & 1 \\
\hline & $\begin{array}{l}\text { Salah dalam mengidentifikasi yang termasuk } \\
\text { contoh atau bukan contoh dari konsep yang } \\
\text { diperoleh }\end{array}$ & 0 \\
\hline \multirow[t]{5}{*}{ 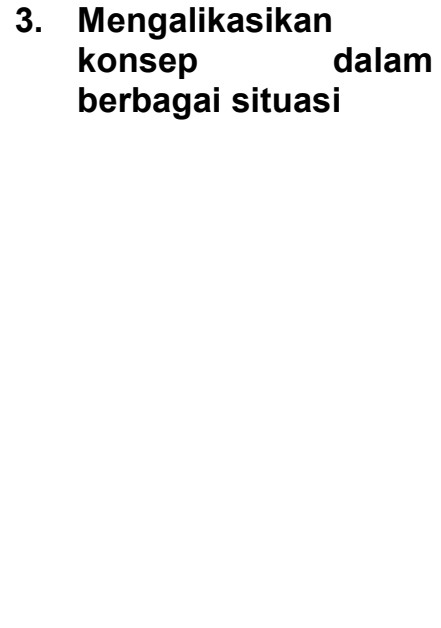 } & $\begin{array}{l}\text { Mengaplikasikan konsep dalam berbagai situasi } \\
\text { dengan benar, perhitungan dan jawaban akhir } \\
\text { benar }\end{array}$ & 4 \\
\hline & $\begin{array}{l}\text { Mengaplikasikan konsep dalam berbagai situasi } \\
\text { dengan benar, sebagian besar perhitungan benar } \\
\text { namun jawaban akhir salah }\end{array}$ & 3 \\
\hline & $\begin{array}{l}\text { Mengaplikasikan konsep dalam berbagai situasi } \\
\text { dengan benar tetapi perhitungan dan jawaban } \\
\text { akhir salah. }\end{array}$ & 2 \\
\hline & $\begin{array}{l}\text { Tidak benar mengaplikasikan konsep dalam } \\
\text { berbagai situasi }\end{array}$ & 1 \\
\hline & $\begin{array}{l}\text { Tidak membuat jawaban atau hanya mengulang } \\
\text { informasi yang diketahui dari soal }\end{array}$ & 0 \\
\hline
\end{tabular}

(dimodifikasi dari NCTM, 2000)

Selain itu data tanggapan siswa terhadap penerapan model pembelajaran kooperatif tipe IOC dikumpulkan menggunakan angket tanggapan siswa diberikan pada saat akhir penelitian. Kriteria penilaian tanggapan menggunakan Skala Likert dengan masing-masing 5 pilihan yaitu Sangat Setuju (SS), Setuju (S), Kurang Setuju (KS), Tidak Setuju (TS), dan Sangat Tidak Setuju (STS).

\section{HASIL DAN PEMBAHASAN \\ HASIL \\ Hasil Penelitian Refleksi Awal}

Pada tahap refleksi awal, siswa kelas VII.1 SMPN 2 Singaraja diberikan tes awal pemahaman konsep matematika berbentuk soal uraian. Dari hasil analisis data pemahaman konsep matematika siswa sebelum pelaksanaan tindakan terlihat bahwa nilai terendah adalah 30 dan nilai tertinggi adalah 90 .

Persentase banyaknya siswa yang belum tuntas adalah $71,88 \%$ (23 orang), sedangkan persentase banyaknya siswa yang sudah tuntas adalah $28,12 \%$ (9 orang). Sebaran pemahaman konsep matematika siswa pada refleksi awal disajikan dalam Gambar 1.1 berikut. 
Grafik Sebaran Data Tes Awal

Pemahaman Konsep Siswa Kelas VII.1

- Tuntas $\quad$ Tidak Tuntas

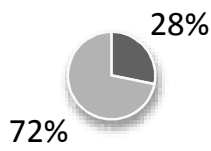

$\begin{array}{clr}\text { Gambar 1.1 } & \text { Sebaran Data Tes Awal } \\ & \text { Pemahaman } \\ & \text { Matematika Siswa }\end{array}$

Berdasarkan tes awal yang diberikan, jumlah total skor pemahaman konsep matematika siswa adalah 1900 dengan banyak siswa adalah 32 orang, sehingga rata-rata skor pemahaman konsep matematika siswa adalah 59,38. Jika dibandingkan dengan kriteria ketuntasan pemahaman konsep matematika siswa yang sudah ditetapkan sebelumnya maka ratarata skror pemahaman konsep matematika siswa pada refleksi awal ini tergolong belum tuntas.

\section{Hasil Penelitian Siklus I}

Pada akhir siklus I siswa diberikan tes pemahaman konsep matematika yang terdiri dari empat butir soal uraian. Dari analisis data tersebut diperoleh rata-rata skor pemahaman konsep matematika siswa adalah 63,44 dan ketuntasan belajar secara klasikal 46,88\% yaitu hanya 15 siswa dari 32 siswa yang mampu mencapai KKM. Adapun sebaran data pemahaman konsep matematika siswa dapat diperhatikan pada gambar 1.2 berikut.

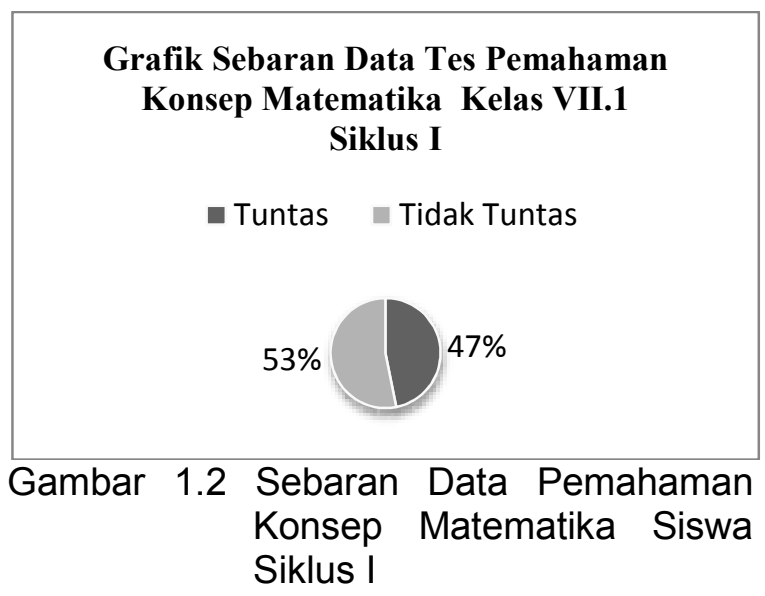

Dapat disimpulkan bahwa rata-rata skor pemahaman konsep matematika siswa pada siklus I belum memenuhi kriteria indikator keberhasilan yang telah ditetapkan.

\section{Hasil Penelitian Siklus II}

Pada akhir siklus II siswa diberikan tes pemahaman konsep matematika yang terdiri dari empat butir soal uraian. Dari analisis data tersebut diperoleh rata-rata skor pemahaman konsep matematika siswa adalah 70,63 dan ketuntasan belajar secara klasikal 59,38\%. Dengan demikian, banyaknya siswa yang tuntas adalah 19 dari 32 orang, sedangkan persentase banyaknya siswa yang tidak tuntas adalah 40,62\% (13 orang). Sebaran data skor pemahaman konsep matematika siswa siklus II disajikan pada gambar 1.3 berikut.

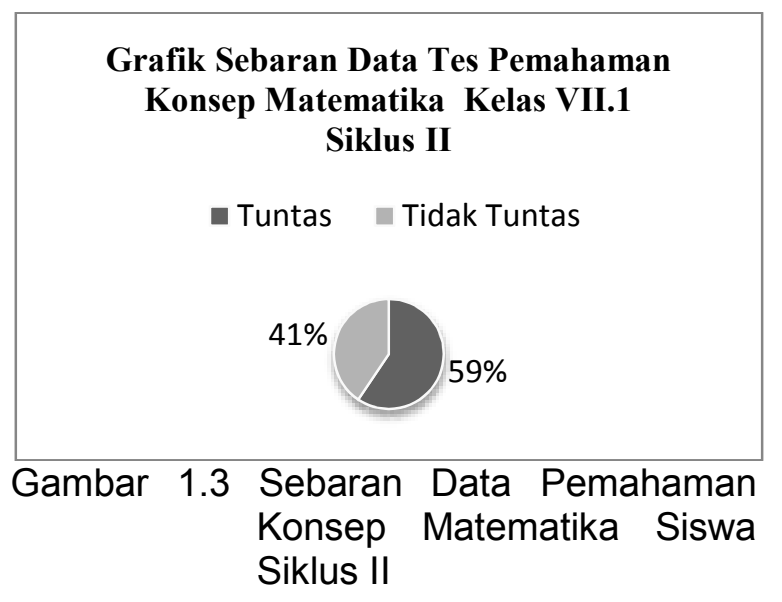

Berdasarkan analisis data di atas, dapat disimpulkan bahwa rata-rata skor pemahaman konsep matematika siswa pada siklus II belum memenuhi kriteria indikator keberhasilan yang telah ditetapkan, karena rata-ratanya berada di bawah 75 yaitu 70,63. Selain itu, ketuntasan belajar siswa secara klasikal juga kurang dari $80 \%$ yaitu $59,63 \%$ sehingga masih berada dalam kategori belum tuntas. Walaupun demikian, rata-rata skor pemahaman konsep matematika siswa dan ketuntasan belajar siswa sudah mengalami peningkatan dari siklus I ke siklus II.

\section{Hasil Penelitian Siklus III}

Pada akhir siklus III siswa diberikan tes pemahaman konsep matematika yang 
terdiri dari tiga butir soal uraian. Dari analisis data tersebut diperoleh rata-rata skor pemahaman konsep matematika siswa pada siklus III adalah 81,88 dan ketuntasan belajar secara klasikal $81,25 \%$. Dengan demikian, banyaknya siswa yang tuntas adalah 26 orang, sedangkan banyaknya siswa yang tidak tuntas adalah 18,75\% (6 orang). Sebaran data skor pemahaman konsep matematika siswa siklus III disajikan pada gambar 1.4 berikut.

\section{Grafik Sebaran Data Tes Pemahaman Konsep Matematika Kelas VII.1 Siklus III}

- Tuntas $\square$ Tidak Tuntas

$19 \%$

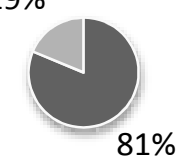

Gambar 1.4 Sebaran Data Pemahaman Konsep Matematika Siswa Siklus III

Berdasarkan analisis data di atas, dapat disimpulkan bahwa rata-rata skor pemahaman konsep matematika siswa pada siklus III sudah memenuhi kriteria indikator keberhasilan yang telah ditetapkan dan mengalami peningkatan dari siklus II. Hal tersebut dapat dilihat dari rata-rata skor pemahaman konsep matematika siswa berada di atas 75 yaitu 81,88 . Selain itu, dan ketuntasan belajar siswa secara klasikal lebih dari $80 \%$ yaitu $81,25 \%$.

\section{Peningkatan Pemahaman Konsep Matematika Siswa}

Peningkatan rata-rata skor pemahaman konsep matematika siswa ditunjukkan dengan grafik seperti Gambar 1.5 berikut ini.

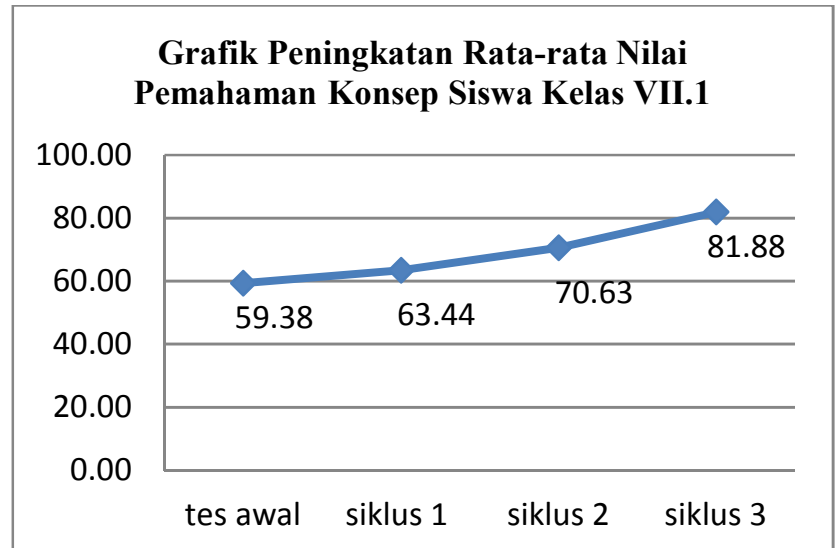

Gambar 1.5 Grafik Peningkatan Rata-Rata

Nilai pemahaman konsep matematika siswa

Peningkatan rata-rata skor pemahaman konsep matematika siswa dari siklus I ke siklus II sebesar 6,25. Sedangkan peningkatan dari siklus II ke siklus III sebesar 12,19. Sehingga untuk peningkatan pemahaman konsep matematika dari siklus I ke siklus III sebesar 18,44 . Hal ini berarti bahwa rata skor pemahaman konsep siswa mengalami peningkatan dari siklus I sampai siklus III sebesar 18,44.

Peningkatan ketuntasan belajar siswa ditunjukkan dengan grafik seperti Gambar 1.6 berikut ini.

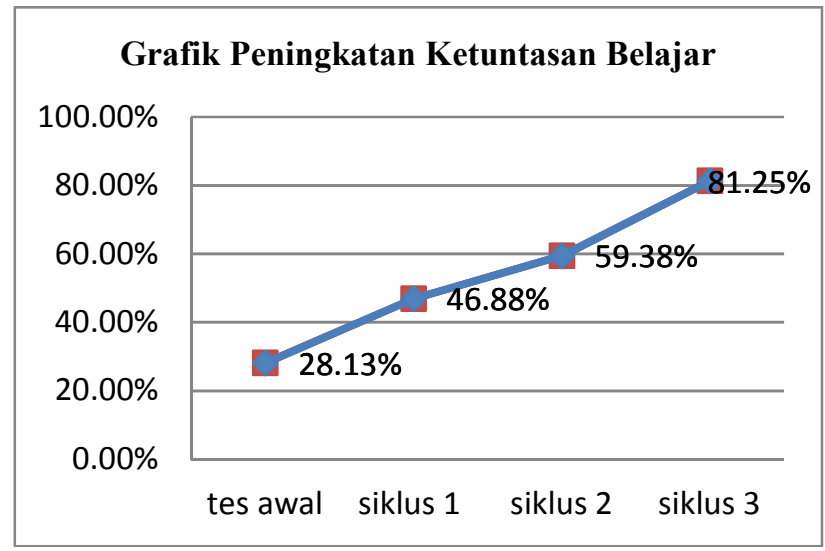

Gambar 1.6 Grafik Peningkatan Ketuntasan Belajar Siswa

\section{Proses Peningkatan Pemahaman Konsep Matematika Siswa}

Proses peningkatan pemahaman konsep matematika siswa melalui model pembelajaran kooperatif tipe TSTS adalah dengan melaksanakan proses pembelajaran dengan baik dengan memperhatikan 
kegiatan pembuka, inti, dan penutup pelajaran. Guru juga memperhatikan kendala-kendala yang ditemukan selama proses pembelajaran dan mencari solusi atas kendala tersebut agar terjadi peningkatan proses pembelajaran di setiap siklusnya.

\section{Tanggapan Siswa}

Pada akhir pertemuan siklus III, siswa juga diberikan angket untuk mengetahui tanggapan siswa terhadap penerapan model pembelajaran kooperatif tipe TSTS. Data mengenai tanggapan siswa terhadap penerapan model pembelajaran kooperatif tipe TSTS dikumpulkan pada akhir siklus III dengan menggunakan angket tanggapan siswa yang terdiri dari 15 butir pernyataan. Berdasarkan data tersebut diperoleh ratarata skor tanggapan siswa terhadap penerapan model pembelajaran kooperatif tipe TSTS selama proses pembelajaran adalah 55,53 .

Sebaran data tanggapan siswa disajikan pada Gambar 1.7 berikut.

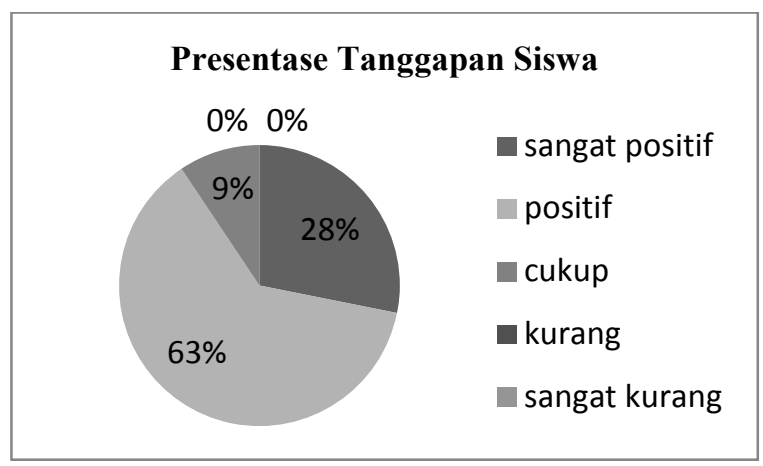

Gambar 1.7 Persentase Tanggapan Siswa

Berdasarkan rata-rata skor tanggapan siswa $(\bar{T}=55,53)$, dapat disimpukan bahwa pembelajaran melalui model pembelajaran kooperatif tipe TSTS mendapatkan tanggapan yang positif dari siswa sesuai dengan kriteria penggolongan tanggapan siswa sehingga tanggapan siswa terhadap penerapan model pembelajaran kooperatif tipe TSTS sudah memenuhi kriteria indikator keberhasilan.

\section{PEMBAHASAN}

Berdasarkan hasil penelitian yang telah dilaksanakan selama tiga siklus menunjukkan terjadinya peningkatan pemahaman konsep matematika siswa kelas VII.1 SMPN 2 Singaraja melalui penerapan model kooperatif tipe TSTS, dan telah memenuhi indikator keberhasilan pada penelitian. Adapun hal-hal yang menyebabkan terjadinya peningkatan pemahaman konsep matematika siswa kelas VII.1 SMPN 2 Singaraja melalui penerapan model kooperatif tipe TSTS sebagai berikut.

Pertama, pembelajaran dengan menerapkan model kooperatif tipe TSTS memberikan kesempatan siswa untuk belajar matematika dengan lebih aktif. Model pembelajaran kooperatif tipe TSTS menekankan pada aktivitas siswa dalam memunculkan suatu model matematika sebagai suatu solusi dari permasalahan yang diberikan. Aktivitas siswa dalam memunculkan model matematika tersebut berdasarkan langkah-langkah pembelajaran pada kooperatif tipe TSTS. Selain itu, dengan diberikannya permasalahan yang bersifat kontekstual, membuat siswa tertarik dalam menyelesaikannya karena permasalahan yang diberikan dirasa dekat dengan kehidupan siswa menjadikan suasana menyenangkan bagi siswa. Dengan kata lain proses pembelajaran akan lebih bermakna sehingga menjadikan siswa lebih memahami konsep matematika. Pada pembelajaran kooperatif tipe TSTS siswa juga dilatih untuk mengembangkan kreatifitas, ini menjadikan siswa akan lebih mandiri dalam menyelesaikan permasalahan yang ada serta mengkontruksi sendiri pengetahuannya. Hal ini sesuai dengan Suherman, dkk (2003) bahwa dengan menerapkan pembelajaran kelompok dalam proses pembelajaran siswa dapat mendiskusikan masalah yang dihadapi, saling bertukar ide, dan memperdebatkan solusi yang akan digunakan.

Kedua, kegiatan pembelajaran menekankan siswa untuk mengkonstruksi sendiri pengetahuannya serta memberikan kesempatan kepada siswa untuk mengembangkan ide, gagasan atau cara yang digunakan untuk menyelesaikan permasalahan yang diberikan. Pada tahap ini materi disajikan dalam bentuk permasalahan pada LKS, permasalahan 
tersebut akan menggiring siswa pada materi pembelajaran yang akan disampaikan.

Ketiga, peran guru dalam kegiatan pembelajaran. Guru senantiasa membimbing dan menuntun siswa, terutama siswa yang memiliki kesulitan dalam memamahi permasalahan yang diberikan. Guru meminta siswa untuk mencermati dengan membaca berulang kali permasalahan yang ada, menuntun siswa untuk menemukan informasi atau pernyataan yang diketahui (current state) serta pernyataan yang akan dituju (goal state) dalam suatu masalah. Peran guru tersebut sesuai dengan yang disampaikan oleh Sudiarta (2008) bahwa guru berperan sebagai fasilitator dalam proses pembelajaran memiliki pengertian bahwa guru selalu membimbing dan mengarahkan siswa dalam proses penyelesaian masalah.

Keempat, guru juga memberikan motivasi kepada siswa yang belum terlibat aktif dalam kegiatan pembelajaran. Seperti yang diketahui pada kegiatan diskusi siklus I dan II masih didomonasi oleh siswa yang sama padahal pemberian masalah pada LKS seharusnya mampu mendorong siswa untuk memiliki jawaban dan cara yang berbeda dengan siswa yang lainnya. Maka dari itu, pemberian motivasi kepada siswa lainnya untuk dapat berpartisipasi dalam kegiatan pembelajaran sangatlah penting.

Selain itu, peningkatan yang telah dicapai tidak terlepas dari penerapan model pembelajaran kooperatif tipe TSTS dengan tahap-tahap yang terdapat dalam kooperatif tipe TSTS yang diberikan yaitu adanya kegiatan diskusi dan melatih siswa untuk belajar lebih bermakna. Selain itu penerapan model pembelajaran kooperatif tipe TSTS ini mendorong siswa berperan aktif dalam proses pembelajaran.

Siswa juga akan menyadari bahwa belajar matematika bukan hanya terpaku pada hasil akhir saja, tetapi proses untuk mendapatkan jawaban akhir tersebut juga penting. Hal ini membuat siswa menyadari bahwa pentingnya untuk mereka memahami konsep dari suatu materi yang akan membuat mereka lebih mudah dalam menerapkan konsep tersebut. Dengan demikian, pembelajaran akan menjadi lebih bermakna. Sesuai dengan pendapat Basir (2016), pemahaman terhadap konsep- konsep matematika merupakan dasar untuk belajar matematika secara bermakna.

Berdasarkan hasil pengamatan selama melaksanakan penelitian, siswa tampak antusias dan bekerja sama dengan baik dalam kelompok untuk mengerjakan masalah yang ada pada LKS. Hal ini didukung pula oleh tanggapan siswa terhadap pembelajaran yang tergolong positif. Akan tetapi, walaupun hampir seluruh siswa memberikan respon positif terhadap penerapan pembelajaran kooperatif tipe TSTS, masih terdapat siswa yang mengalami kesulitan ketika diterapkannya model pembelajaran kooperatif tipe TSTS. Beberapa siswa mengatakan bahwa memiliki kesulitan dalam mengikuti petunjuk LKS dan memahami permasalahan yang diberikan serta lebih nyaman atau menyenangi kegiatan pembelajaran ketika guru yang menjelaskan dibandingkan dengan diskusi kelompok yang mengharuskan siswa untuk mengkonstruksi dan mengeksplorasi pengetahuannya sendiri. Hal ini disebabkan karena siswa telah terbiasa dengan model pembelajaran yang diterapkan oleh gurunya sehingga beberapa siswa masih menyesuaikan diri dengan diterapkannya pembelajaran kooperatif tipe TSTS. Namun secara umum, siswa kelas VII.1 telah merespon positif penerapan pembelajaran kooperatif tipe TSTS, ini berarti model pembelajaran kooperatif tipe TSTS menjadi salah satu alternatif solusi untuk pembelajaran di kelas.

Berdasarkan hasil yang diperoleh, penelitian ini telah mampu menjawab rumusan masalah sekaligus memecahkan permasalahan yang ada di kelas VII.1 SMPN 2 Singaraja. Dengan demikian, hasil penelitian ini telah memenuhi semua indikator keberhasilan yang telah ditetapkan. Jadi, dapat disimpulkan penelitian ini sudah berhasil.

\section{SIMPULAN DAN SARAN Simpulan}

Berdasarkan hasil analisis data dan pembahasan hasil penelitian, diperoleh simpulan secara umum terjadi peningkatan 
pemahaman konsep matematika siswa kelas VII.1 SMPN 2 Singaraja. Hal ini disebabkan karena disetiap kegiatan pembelajaran kooperatif tipe TSTS mengajak siswa untuk fokus dan memusatkan perhatiannya dalam mengikuti proses pembelajaran. Selain itu, dengan penerapan model pembelajaran kooperatif tipe TSTS membuat siswa lebih antusias dalam belajar karena pada model ini membangun pengetahuannya dengan diskusi kelompokn, dan setiap kelompok di bombing oleh guru dan membuat siswa menjadi lebih aktif dalam mengikuti pembelajaran. Hal ini telah didukung dengan rata-rata nilai pemahaman konsep yang diperoleh siswa selama pembelajara mengalami peningkatan pada setiap siklusnya. Rata-rata skor pemahaman konsep siswa pada siklus I adalah 63,44; pada siklus II adalah 70,63; pada siklus III adalah 81,88. Dari siklsu I ke siklus II terjadi peningkatan sebesar 7,19; dan dari siklus II ke siklus III mengalami peningkatan sebesar 11,25. Rata-rata Tanggapan siswa terhadap model kooperatif tipe TSTS yang dikumpulkan melalui angket telah berada dalam kategori sangat positif sebanyak 9 orang, positif sebanyak 20 orang dan cukup positif sebanyak 3 orang sehingga banyaknya siswa yang memberikan tanggapan dalam kategori positif adalah 29 dari 32 orang. Secara keseluruhan tanggapan siswa terhadap penerapan model pembelajaran kooperatif tipe TSTS dalam kategori positif dengan rata-rata skor tanggapan siswa sebesar 55,53, hal ini sesuai dengan indikator keberhasilan dalam penelitian ini.

\section{Saran}

Berdasarkan hasil penelitian yang diperoleh, adapun saran yang penuiis dapat sampaikan yaitu sebagai berikut.

Diharapkan Model kooperatif tipe TSTS dapat dijadikan salah satu alternatif dalam melaksanakan pembelajaran matemtaika, sehingga pembelajaran yang dilaksanakan lebih variatif seperti yang telah dilaksanakan sebelumnya dan dapat meningkatkan pemahaman konsep matematika siswa.
Kepada pembaca yang berminat untuk mengadakan penelitian lebih lanjut sebagai penyempurnaan mengenai Model kooperatif tipe TSTS dengan memperhatikan kendala-kendala yang peneliti alami sebagai bahan pertimbangan.

\section{UCAPAN TERIMA KASIH} kepada:

Ucapan Terima Kasih ditujukan

Dr. I Made Sugiarta, M.Si selaku pembimbing I dengan kesabaran, kecermatan, ketelitian dan tidak pernah bosan untuk meluangkan waktu di tengah-tengah kesibukan beliau untuk memberikan bimbingan, motivasi, arahan, saran, dan petunjuk dalam menyelesaikan skripsi ini.

Prof. Dr. I Gusti Putu Suharta, M.Si selaku pembimbing II yang dengan kesabaran, kecermatan, ketelitian, dan tidak pernah bosan untuk meluangkan waktu di tengah-tengah kesibukan beliau untuk memberikan bimbingan, motivasi, arahan, saran dan petunjuk selama perkuliahan, awal penyusunan skripsi hingga terselesaikannya skripsi ini.

Nyoman Purnayasa, S.Pd., M.M, selaku Kepala SMPN 2 Singaraja yang telah memberikan ijin kepada penulis untuk mengadakan penelitian di sekolah yang dipimpinnya.

I Gede Widiarta, S.Pd selaku guru Matematika di kelas SMPN 2 Singaraja, atas segala bantuan dan kerjasamanya selama penulis mengadakan penelitian.

\section{DAFTAR PUSTAKA}

Depdiknas.2006. Standar Isi Untuk Satuan Pendidikan Dasar dan Menengah. Jakarta: Badan Standar Nasional Pendidikan 
Handayani, Mimi dkk "Pengaruh Model

Pembelajaran Two Stay Two Stray

Terhadap Pemahaman Konsep

Matematis Siswa" Vol.3 No.1(2014) :

Jurnal Pendidikan Matematika part

1Hal. 56-60 (diakses pada tanggal 13

september 2018)

Koyan, I Wayan. 2011. Assesmen dalam Pendidikan. Singaraja: UNDIKSHA Press

Lestari, Nurdiana, dkk. "Penerapan Model Kooperatif Tipe Two Stay Two Stray dengan Media Gambar dalam Peningkatan Pembelajaran Matematika Siswa Kelas V SD Negeri 1 Kutowinangun." Vol.6, No. 1, (2018). http://jurnal.fkip.uns.ac.id/index.php/pg sdkebumen/article/view/3686 (8 Maret 2018).

Lie, A. 2008. Cooperative Learning: Mempraktikan Cooperative Learning Di Ruang-ruang Kelas. Jakarta: Grasindo.

NCTM. 2000. Principles and Standards for School Mathematics. Reston VA:NCTM.

Sanjaya, Wina. 2008. Perencanaan dan Desain Sistem Pembelajaran. Jakarta: Kencana Prenada Media Group.

Sanjaya, Wina. 2009. Penelitian Tindakan Kelas. Jakarta: Kencana Prenada Media Group. 